\title{
Lepus corsicanus gastro-intestinal helminths: first report
}

\author{
F. USAI ${ }^{1}$, R. RINNOVATI $^{1}$, V. TROCCHI ${ }^{2}$, L. STANCAMPIANO ${ }^{1}$
}

\begin{abstract}
${ }^{1}$ Department of Veterinary Medical Sciences, Alma Mater Studiorum - Università di Bologna, Via Tolara di Sopra, 50 - 40064 Ozzano dell'Emilia (Bologna), Italy, E-mail: laura.stancampiano@unibo.it; ${ }^{2}$ Italian National Institute for Environmental Protection and Research - I. S. P. R. A., Via Ca' Fornacetta, 9-40064 Ozzano dell'Emilia (Bologna), Italy
\end{abstract}

\begin{abstract}
Summary
Italian hare Lepus corsicanus De Winton, 1898, is a true species living in simpatry with Lepus europaeus in mainland Italy and with Oryctolagus cuniculus in Sicily, where L. europaeus is absent. Up to date, nobody has studied the helminths of this endemic Italian Mammal. Therefore, in order to describe Italian hare gastro-intestinal helminths, gastro-intestinal tract of 29 Italian hares, coming from mainland Italy (\#14) and from Sicily (\#15) were collected between 1997 and 2009. Twentyfive hares were positive for at least one parasite $(86 \%)$. Six parasite species were isolated, 2 cestodes (Cittotaenia pectinata, prevalence $3 \%$ ) and Paranoplocephala sp., $3 \%$ ) and 4 nematodes (Trichostrongylus retortaeformis, $86 \%$, Graphidium strigosum, $14 \%$, Trichuris sp., $10 \%$ and Teladorsagia circumcincta, $7 \%$ ). Both Teladorsagia circumcincta circumcincta and Teladorsagia circumcincta trifurcata morphotypes were identified. Comparison with available data regarding $L$. europaeus and $O$. cuniculus in Italy is provided. Being not $T$. circumcincta and Paranoplocephala sp. typical parasites of leporids, a description of the observed specimens is given.
\end{abstract}

Keywords: Lepus corsicanus; helminths; Italy

\section{Introduction}

Italian hare Lepus corsicanus De Winton, 1898, formerly considered a subspecies of European brown hare Lepus europaeus Pallas, 1778, is an italian endemic species rediscovered by means of morphological (Palacios et al., 1989; Palacios, 1996; Riga et al., 2001) and molecular analyses (Pierpaoli et al., 1999). In its natural range no morphological and genetic hybrids were found in areas where viable populations of $L$. corsicanus and $L$. europaeus coexist in simpatry. Phylogenetical analyses suggested that $L$. corsicanus and L. europaeus are not closely related sister taxa, but belong to distinct evolutionary line- ages that dispersed in Western Europe in different periods during the early Pleistocene (Pierpaoli et al., 1999).

The current distribution of $L$. corsicanus is still poor known. This threatened species is found in Central and Southern mainland Italy and in Sicily; its mainland status is classified as "vulnerable" (Angelici et al., 2008). In Sicily the species seems relatively more abundant but possibly in decline (Angelici \& Luiselli, 2001). Populations of $L$. corsicanus in mainland Italy are in sympatry and syntopy with L. europaeus, while in Sicily, where European brown hare is absent, L. corsicanus lives in sympatry and syntopy with wild rabbit, Oryctolagus cuniculus.

Up to date, the only reports of parasites in Italian hare regard EBHS virus (Guberti et al., 2000) and ticks (Dantas-Torres et al., 2011) while nobody has studied the helmints of this endemic Italian Mammal. Therefore, coherently with the National Action Plan (Trocchi \& Riga, 2001) that emphasises the importance of scientific research on $L$. corsicanus diseases in natural areas, we carried out a preliminar analysis of Italian hare gastro-intestinal helminths biocenosis.

\section{Materials and methods}

Gastro-intestinal tract of 29 Italian hares have been collected from their whole living area, in Italy, between 1997 and 2008 by I.N.F.S. (National Institute for Wildlife, nowadays merged into I.S.P.R.A. - National Institute for Environmental Research). Age estimation has been attained on the basis of skull ossification and development (CabonRaczynska, 1964).

The gastro-intestinal tract was preserved in $10 \%$ formalin (\#19) or frozen at $-20^{\circ} \mathrm{C}(\# 10)$, and examined between October 2008 and October 2009. Stomach and intestine were longitudinally opened, gently scraped with a microscope slide to allow the detaching of parasites, and washed with tap water. Their content was than collected in conical flasks and repeatedly washed in order to obtain the sediment 
Table 1. Description of the 29 specimens of Lepus corsicanus examined for gastro-intestinal helminths collection

\begin{tabular}{|c|c|c|c|c|}
\hline & & $\begin{array}{l}\text { Sicily } \\
(\# 15) \\
\end{array}$ & $\begin{array}{c}\text { Continental } \\
\text { Italy (\#14) }\end{array}$ & total \\
\hline \multicolumn{5}{|l|}{ sex } \\
\hline & male & 8 & 5 & 13 \\
\hline & female & 7 & 9 & 16 \\
\hline \multicolumn{5}{|l|}{ age } \\
\hline & young* & - & 2 & 2 \\
\hline & sub-adult & 2 & 2 & 3 \\
\hline & adult & 13 & 12 & 25 \\
\hline \multirow{5}{*}{$\begin{array}{l}\text { cause } \\
\text { of death }\end{array}$} & & & & \\
\hline & legally shot & & & \\
\hline & for study purpose & 15 & 8 & 23 \\
\hline & $\begin{array}{l}\text { found dead** } \\
\text { dead }\end{array}$ & - & 3 & 3 \\
\hline & in captivity*** & - & 3 & 3 \\
\hline
\end{tabular}

to be screened under a stereomicroscope for parasite collection. Collected helminths were fixed in a $70 \%$ ethanol solution with $5 \%$ glycerol. Cestodes were stained in acetoalum-carmine solution, mounted in Canada-balsam and identified using the key and description of Tenora et al., (1986), Haukisalmi and Henttonen (2003), Haukisalmi and Wickström (2005), Haukisalmi (2009). Nematodes were clarified and mounted in lactophenol, and identified using the keys and descriptions of Erickson (1944), Soulsby (1968), Becklund and Walker (1971), Stringfellow (1972), Gibbons and Khalil (1982), Lichtenfels and Hoberg (1993). For Trichostrongylidae, the number of female belonging to each species was estimated based on the number of males. Some damaged or sexually immature nematodes were classed at family level only.

Prevalence and abundance of each parasite species were computed according to Margolis et al. (1982) and Bush et al. (1997). Confidence intervals (CI) for prevalences and abundances were calculated using the statistical package QP 3.0 (Reiczigel \& Rózsa, 2005).
A sample of the isolated parasites and a copy of the raw working data are available from the Authors.

\section{Results}

Main features of the examined animals are summarized in Table 1.

Out of 29 hares, 25 were positive for at least one parasite (86 \%). Six parasite species were isolated, 2 cestodes (Cittotaenia pectinata and Paranoplocephala sp.) and 4 nematodes (Trichostrongylus retortaeformis, Graphidium strigosum, Trichuris sp. and Teladorsagia circumcincta which comprises Teladorsagia circumcincta circumcincta and Teladorsagia circumcincta trifurcata morphotypes). Trichostrongylidae fourth stage larvae were also collected. Range, prevalence, abundance, sex ratio and localization of the isolated parasites are summarized in Table 2.

All the 53 specimens of $C$. pectinata collected belonged to a single host, an adult female shot in 1999 in continental Italy. The two specimens of Paranoplocephala sp. were recovered in the small intestine of one female shot in Sicily in 2008. The 11 males of $T$. c. circumcincta morphotype were found in the stomach of two animals, an adult female shot in 1997 in Sicily and a sub-adult male shot in 1997 in Sicily, with 9 and 1 intensity, respectively. The 3 male nematodes identified as $T$. c. trifurcata were found in one animal only, the same adult female shot in 1997 in Sicily which had the higher intensity of $T$. c. circumcincta. Trichuris sp. was found in continental Italy only, while $T$. retortaeformis and $G$. strigosum were collected both in continental Italy and in Sicily.

Being not $T$. circumcincta and Paranoplocephala sp. typical parasites of leporids, a description of the observed specimens will be given in the following sections.

Paranoplocephala sp. (Fig. 1)

Strobila relatively thin with large scolex, $0.6 \mathrm{~mm}$ wide, bearing four ovoid protruding suckers, large relative to scolex, crateriform in side view, $0.35 \mathrm{~mm}$ in maximum

Table 2. Helminths collected from 29 Lepus corsicanus in Italy from 1997 to 2008

\begin{tabular}{|c|c|c|c|c|c|c|}
\hline & & range $^{\circ}$ & $\begin{array}{c}\text { Prevalence } \% \\
(95 \% \mathrm{CI})\end{array}$ & $\begin{array}{c}\text { Abundance } \\
(95 \% \mathrm{CI})\end{array}$ & $\begin{array}{c}\text { Sex Ratio } \\
(\mathrm{M}: \mathrm{F})\end{array}$ & localization \\
\hline \multicolumn{7}{|l|}{ Nematodes } \\
\hline & Trichostrongylus retortaeformis & $1-171$ & $86(68-96)$ & $14.59(6.97-35.59)$ & $1: 1.4$ & intestine \\
\hline & Graphidium strigosum & $4-67$ & $14(4-32)$ & $3.28(0.52-12.38)$ & $1: 1.6$ & stomach \\
\hline & Teladorsagia circumcincta§ & $2-76$ & $7(1-23)$ & $2.69(0.00-10.62)$ & $1: 5.0$ & stomach \\
\hline & T. c. circumcincta & $2-57$ & $7(1-23)$ & $2.03(0.00-8.07)$ & $1: 4.9$ & \\
\hline & T. c. trifurcata & $19-19$ & $3(0.1-18)$ & $0.66(0.00-1.97)$ & $1: 5.3$ & \\
\hline & Trichuris sp. & $1-5$ & $10(2-27)$ & $0.31(0.03-0.90)$ & $1: 0.3$ & intestine \\
\hline & $\mathrm{L} 4 *$ & $7-26$ & $7(1-23)$ & $1.14(0.00-3.83)$ & / & stomach, intestine \\
\hline & Trichostrongylidae** & $1-179$ & $86(68-96)$ & $17.72(9.10-40.34)$ & $1: 1.6$ & \\
\hline & Cittotaenia pectinata & $53-53$ & $3(0.1-18)$ & $1.83(0.00-5.48)$ & / & intestine \\
\hline & Paranoplocephala sp. & $2-2$ & $3(0.1-18)$ & $0.07(0.00-0.21)$ & 1 & intestine \\
\hline
\end{tabular}

$\circ$ in infected animals

$\S$ include $T$. c. circumcincta and T. c. trifurcata morphotypes

* Trichostrongylidae fourth stage larvae

**Total adult Trichostrongylidae burden, including damaged specimens 

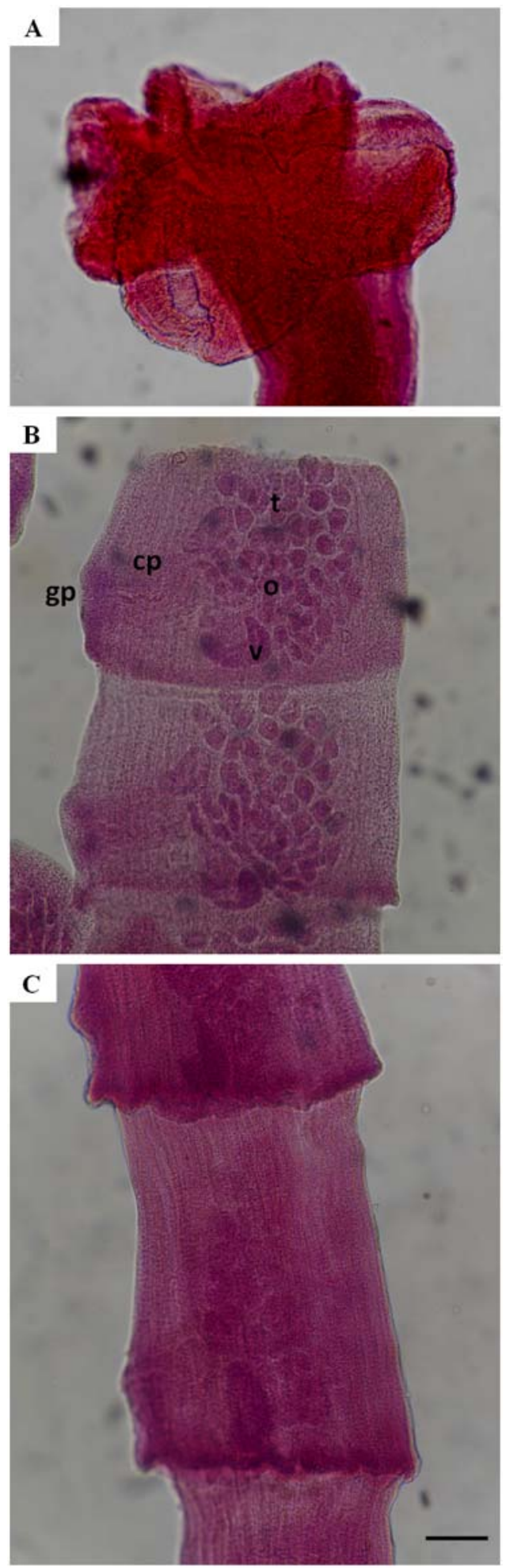

Fig. 1. Paranoplocephala sp. A. Scolex; B. Mature proglottids (t: testes, o: ovary, v: vitellarium, cp: cirrus pouch, gp: genital pore

C. Terminal segment strongly elongate. Scale-bar: $100 \mu \mathrm{m}$.

diameter, directed antero-laterally. Neck $1.55 \mathrm{~mm}$ long, minimum width $0.25 \mathrm{~mm}$.

Craspedote proglottides wider than long (length/width ratio range $0.5-0.7)$; acraspedote proglottides elongated (length/width ratio range $0.7-1.3$ ). Absence of eggs in terminal segments (sterility) which are strongly elongate (length/width ratio range $1.3-1.9$ ). Genitalia single. Genital pores unilateral, opening in posterior half of segment margin. Testes numerous, distributed antiporally and anterior to ovary. Vitellarium asymmetrically bilobed overlapping posterior margin of ovary. Ovary in median position with margin coarsely lobed. Uterus not visible.

\section{Teladorsagia circumcincta (Fig 2) \\ Teladorsagia circumcincta circumcincta}

Male copulatory bursa with two large lateral lobes and a reduced separate dorsal lobe. Rays of copulatory bursa in 2-2-1 pattern. Ventral rays diverging and coming together at their distal tips; anteroventral ray smaller than posteroventral ray; externodorsal ray arising from the base of the dorsal ray; dorsal ray slender, with one pair of long branches, arising halfway from the main trunk, dividing again at their distal end; dorsal raylets widely spaced, surrounded by an accessory bursal membrane unsclerotized. Spicules rod-like, with an average length of $297.9 \mu \mathrm{m}$, branching at their distal fourth. Average body length $7.5 \mathrm{~mm}$.

\section{Teladorsagia circumcincta trifurcata}

Copulatory bursa ray pattern as in T. c. circumcincta. Accessory bursal membrane sclerotized. Spicules stout, with an average length of $223.3 \mu \mathrm{m}$ ending with two sharp spurs given off medially just behind the middle and with a large knobbed tip. Average body length $7.2 \mathrm{~mm}$.

\section{Discussion}

T. retortaeformis, G. strigosum, Trichuris sp. and C. pectinata are common parasites of lagomorphs and have been reported in Europe both in L. europeus (Canestri Trotti et al., 1988; Poglayen et al., 2002; Bordes et al., 2007; Alzaga et al., 2009; Dubinský et al., 2010) and in O. cuniculus (Giannetto et al., 1998; Sorgi et al., 2004; Eira et al., 2007). High frequence and abundance of $T$. retortaeformis and G. strigosum are usually reported in L. europaeus and the present paper indicates their importance also in $L$. corsicanus. On the contrary, the absence of Passalurus ambiguus, usually dominant in European brown hare biocoenosis, is noteworthy. Although the relatively small number of examined Italian hares, the presence of this parasite in O. cuniculus in Sicily (Giannetto et al., 1998; Sorgi et al., 2004) and in L. europaeus in continental Italy (Canestri Trotti et al., 1988; Poglayen et al., 2002) suggests an important role of host specificity in explaining its absence in L. corsicanus. However, we would like to point out that parasitological data regarding European hares from Central and Southern Italy are lacking.

The frequent observation of Trichuris spp. in L. europaeus and the very occasional report in $O$. cuniculus could explain its presence in mainland $L$. corsicanus only, where this species lives in sympatry with $L$. europaeus; the absence of Trichuris spp. in Italian hare in Sicily suggests that this host probably does not play the role of reservoir species for this nematode. 

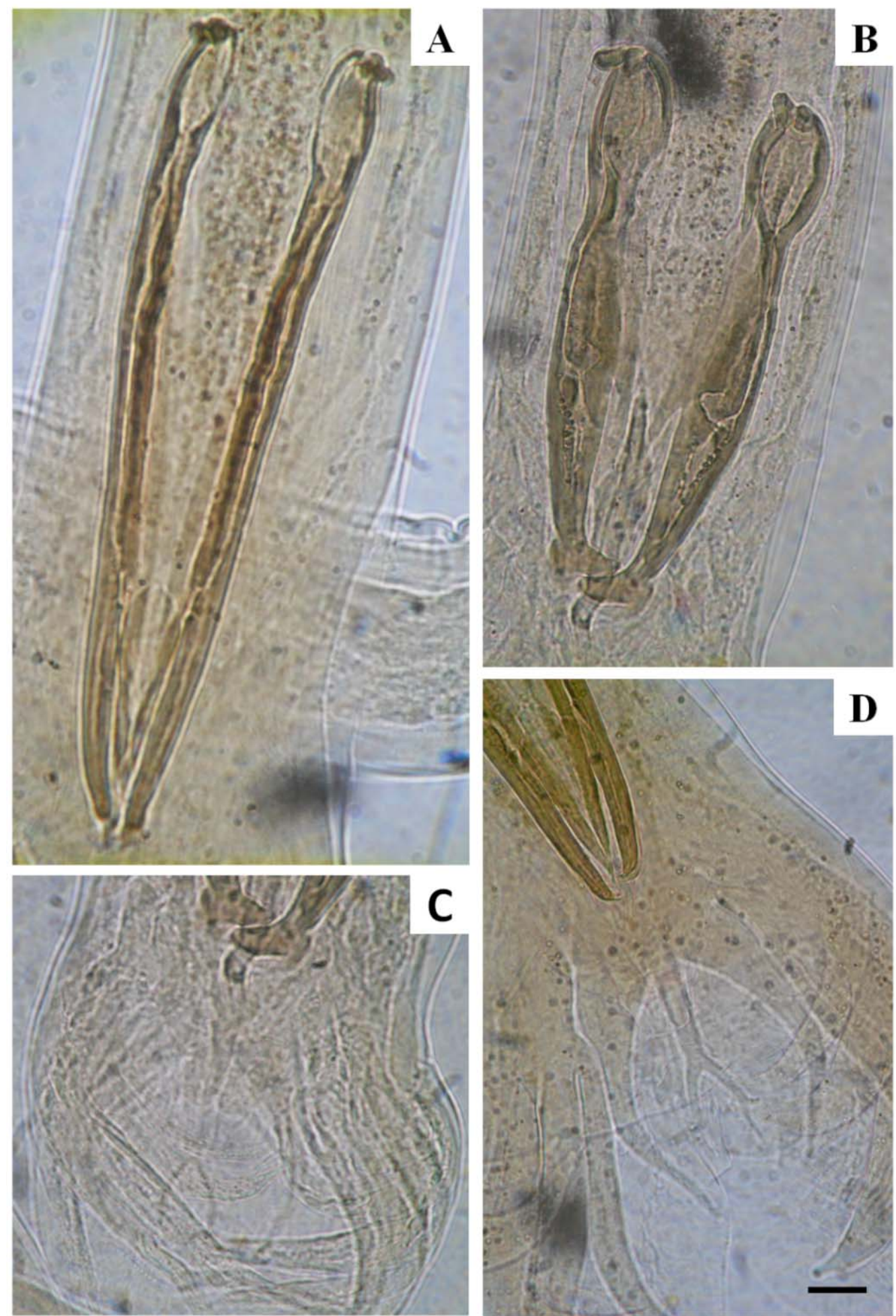

Fig. 2. Teladorsagia circumcincta. A spicules and D copulatory bursa of Teladoragia c. circumcincta; B spicules and D copulatory bursa of Teladorsagia c. trifurcata. Scale-bar: $20 \mu \mathrm{m}$.

\section{Atypical parasites}

Paranoplocephala (sensu lato) is a heterogeneous group of Anoplocephaline cestodes parasitising rodents. The detection of the genus Paranoplocephala in lagomorphs should be considered as the first report. In fact, despite Paranoplocephala wimerosa had been described from hares and rabbits in Europe, and it was for a long time considered the only Paranoplocephala species recorded from lagomorphs (Stunkard, 1941), this species was removed from Paranoplocephala genus since 1976 (Haukisalmi, 2009).

Paranoplocephala is morphologically characterized by a partly or completely reticulate (early) uterus and by testes 
distributed in the antiporal or antiporal and anterior parts of the segment (Tenora et al., 1986; Haukisalmi \& Henttonen, 2003). In our specimens it was not possible to appreciate the uterus but, conversely to previous assumption and according to Haukisalmi and Henttonen (2003), the uterus is not to be considered the main determinant for anoplocephaline systematic. Indeed, the following additional criteria, suggested by Haukisalmi and Wickström (2005), have been used to assign the species to the genus Paranoplcephala and to differentiate it from the similar genus Andrya, typical of leporids: i) the vitellarium of Andrya is positioned posterior to the ovary, whereas in Paranoplocephala spp. the vitellarium substantially overlaps the posterior part of the ovary, ii) the asymmetrically bilobed vitellarium is also characteristic of Paranoplocephala spp. as opposed to Andrya's vitellarium that is more irregular and usually not distinctly bilobed, iii) in addition, the genital pores of Andrya are irregularly alternating (Haukisalmi \& Wickström, 2005).

Finally, the sterility detected in our specimens is an additional feature described only in Paranoplocephala genus, in particular in $P$. macrocephala, P. kalelai, P. omphalodes, $P$. microti and $P$. feodorovi, which are included in the Paranoplocephala sensu stricto group (Haukisalmi \& Henttonen, 2003). Consistently with our observations, sterility is typically accompanied by pronounced morphological changes, especially in terminal segments which are strongly elongate (Haukisalmi \& Henttonen, 2003). It is not known whether sterility is a permanent or transient feature while, according to Haukisalmi and Henttonen (2003) it is probably related nor to the incompatibility with a particular host taxon or to the intensity of infection. Therefore, the sterility of the described specimens does not exclude the adaptation of the parasite to L. corsicanus host species.

This is the first record of natural $T$. circumcincta infection in lerporids. The identification was based upon morphologycal characters typical of this species, differing from the other Trichostrongylidae, in particular those reported in natural infections in leporids and specifically from Obeliscoides cuniculi. This latter differs from our specimens in the morphology and length of the spicules, in the absence of the gubernaculum and in the shape of dorsal ray and dorsal raylets (Graybill, 1923; Erickson, 1944). Moreover, the italian geographical distribution of $O$. cuniculi is restricted to Northern regions, having been reported for the first time in Piedmont in Sylvilagus floridanus (whose import has introduced this parasite) by Tizzani et al. in 2002 and later in sympatric L. europaeus (Meneguz \& Tizzani, 2004).

T.c. circumcincta and T. c. trifurcata have been definitely recognized as morphotypes of the same species (Leignel et $a l ., 2002)$ that always occurs in host population in more or less fixed proportion with predominant $T$. c. circumcincta (Craig et al., 2010). They are typical parasites of ruminants and have never been found in naturally infected lagomorphs. The natural acquisition of ruminant digestive tract nematode species is possible but not frequent in rabbits and hares. For example, Saulai and Cabaret (1998) reported typical ruminant parasites, namely Trichostrongylus colubriformis and Trichostrongylus capricola, in O. cuniculus and Lepus capensis respectively. However these infections were sporadic notwithstanding the high density of ruminant species. In Italy, ruminant parasites - Trichostrongylus vitrinus, T. colubriformis, Trichostrongylus axei and Ostertagia ostertagi - have been reported in O. cuniculus in Sicily (Giannetto et al., 1998) while in Sardinia T. colubriformis and $T$ vitrinus were formerly reported from wild rabbit (Lai \& Arru, 1969). As regards T. circumcincta, experimental infections of lagomorphs with cultured larvae have been proved difficult but achievable in L. europaeus and not in O. cuniculus (Stott et al., 2009). The susceptibility of $L$. corsicanus to $T$. circumcincta is probably peculiar of this host, as this parasite, widespread in both wild and domestic ruminants in Northern Italy (Capelli et al., 1998; Zaffaroni et al., 2000; Stancampiano \& Battelli, 2002; Citterio et al., 2006) has never been recorded in $L$. europaeus from Northern italian areas (Canestri Trotti et al., 1988; Poglayen et al., 2002).

Regarding the role of parasites in Italian hare populations, further analysis of available data, with special attention on parasite biocoenosis and host-parasite relationship, are going to be performed.

\section{References}

Alzaga, V., Tizzani, P., Acevedo, P., Ruiz-Fons, F., VICENTE, J., GORTÀZAR C. (2009): Deviance partitioning of host factors affecting parasitization in the European brown hare (Lepus europaeus). Naturwissenschafte 96: $1157-1168$

ANGEliCI, F. M., Luiselli, L. (2001): Distribution and status of the Apennine hare Lepus corsicanus in continental Italy and Sicily. Oryx, 35: 245 - 249. DOI: 10.1046/j.13 65-3008.2001.00182.x

Angelici, F. M., RANDI, E., RigA, F., Trocchi, V. (2008): Lepus corsicanus. In: IUCN 2010. IUCN Red List of Threatened Species. Version 2010.1. <www.iucnredlist.org> Becklund, W. W., WALKer, M. L. (1971): Nomenclature and morphology of Ostertagia trifurcata Ransom, 1907, with data on spicule lengths of five stomach worms of ruminants. J. Parasitol., 57: 508 - 516

Bordes, F., Langand, J., Feliu, C., Morand S. (2007): Helminth Communities of an Introduced Hare (Lepus granatensis) and a Native Hare (Lepus europaeus) in Southern France. J. Wildl. Dis., 43: 747-751

Bush, A. O., Lafferty, K. D., Lotz, J. M., Shostak, A. W. (1997): Parasitology meets ecology on its own terms: Margolis et al. revisited. J. Parasitol., 83, $575-583$

CABON-RACZYNSKA, K. (1964): Studies on the European hare. III. Morphological variation of the skull. Acta Theriol. 9: $249-285$

Canestri Trotti, G., Corradini, L., BAssi, S. (1988): Osservazioni sulle elmintiasi gastrointestinali di lepri delle province di Ferrara e Modena e lepri di importazione. Suppl. Ric Biol Selvaggina 14: 317 - 321 
Capelli, G., Stancampiano, L., Dal Colle, S., Bozzolan, G., Parenti, E., Pietrobelli M. (1998): Gastrointestinal parasite community in roe deer (Capreolus capreolus) and interactions between wild and domenstic ruminants. Parassitologia 40 (Suppl. 1): 30

Citterio, C. V., Caslini, C., Milani, F., Sala, M., FERRARI, N., LANFRANCHI, P. (2006): Abomasal nematode community in an Alpine chamois (Rupicapra r. rupicapra) population before and after a die-off. J. Parasitol., 92: 918 - 927. DOI: $10.1645 / \mathrm{GE}-3551.1$

Craig, B. H., Pilkington, J. G., Pemberton, J. M. (2010): Sex ratio and morphological polymorphism in an isolated, endemic Teladorsagia circumcincta population. J. Helminthol., 84: 208 - 215. DOI: 10.1017/S0022149X09990551

Dantas-Torres, F., Testini, G., DiGeronimo, P.M., Lorusso, V., Mallia, E., Otranto, D. (2011): Ticks infesting the endangered Italian hare (Lepus corsicanus) and their habitat in an ecological park in southern Italy. Exp. Appl. Acarol., 53: 95 - 102. DOI: 10.1007/s10493010-9387-3

Dubinský, P., VAsilková, Z., Hurníková, Z., MiterPÁKOVÁ, M., SLAMEČKA, J., JURČ́́K, R. (2010): Parasitic infections of the European brown hare (Lepus europaeus Pallas, 1778) in south-western Slovakia. Helminthologia., 47: 219 - 225. DOI: 10.2478/s1 1687-010-0034-7

EIRA, C., Torres, J., MiQuel, J., VingadA, J. (2007): The helminth parasites of the wild rabbit Oryctolagus cuniculus and their effect on host condition in Dunas de Mira, Portugal. J. Helminthol., 81: 239 - 246. DOI: 10.1017/S002214 9X07727426

ERICKSON A. B. (1944): Helminth infections in relation to population fluctuations in snowshoe hares. J. Wildl. Manage., 8: $134-153$

Giannetto, S., Virga, A., Baccarani, E. M., Canestri TROTti G. (1998): Elminti intestinali in conigli selvatici (Oryctolagus cuniculus). Atti SISVet., 52: 165 - 166.

GibBons, L. M., KHALIL, L. F. (1982): A key for the identification of genera of the nematode family Trichostrongylidae Leiper, 1912. J. Helminthol. 56: $185-233$.

GrAYBILL, H. W. (1923): A new genus of nematodes from the domestic rabbit. Parasitology. 12: $340-342$.

Guberti, V., De Marco, M. A., Riga, F., Cavazza, A., Trocchi, V., CAPUCCI, L. (2000): Virology and species conservation: the case of EBHSV and the Italian hare (Lepus corsicanus De Winton, 1898). Proceeding of $V$ International Congress of European Society for Veterinary Virology. 198 - 199

Haukisalmi, V., Henttonen, H. (2003): What is Paranoplocephala macrocephala (Douthitt, 1915) (Cestoda: Anoplocephalidae)? Syst. Parasitol. 54: 53 - 69. DOI: 10.1023/ A:1022141809571

HaUkisalmi, V., WiCKSTRÖM, L. M. (2005): Morphological characterisation of Andrya Railliet, 1893, Neandrya n. g. and Paranoplocephala Lühe, 1910 (Cestoda: Anoplocephalidae) in rodents and lagomorphs. Syst. Parasitol. 62: 209 - 219. DOI: 10.1007/s11230-005-5499-2

HaUkisalmi, V. (2009): A taxonomic revision of the genus Anoplocephaloides Baer, 1923 sensu Rausch (1976), with the description of four new genera (Cestoda: Anoplocephalidae). Zootaxa. 2057: 1 - 31 .

LAI, M., ARRU, E. (1969): Trichostrongylidae del coniglio selvatico (Oryctolagus cuniculus). Parassitologia 11: 97 99

Leignel, V., Cabaret, J., Humbert, J. F. (2002): New molecular evidence that Teladorsagia circumcincta (Nematoda: Trichostrongylidea) is a species complex. J. Parasitol. 88: 135 - 140. DOI: 10.1645/0022-3395(2002)088 [0135:NMETTC]2.0.CO;2

Lichtenfels, J. R., HoberG, E. P. (1993): The systematics of nematodes that cause ostertagiasis in domestic and wild ruminants in North America: an update and a key to species. Vet. Parasitol. 46: 33 - 53. DOI: 10.1016/03044017(88)90056-8

Margolis, L., Esch, G. W., Holmes, J. C., Kuris, A. M., SCHAD, G. A. (1982): The use of ecological terms in parasitology. J. Parasitol., 68: 131 - 133

Meneguz, P. G., TizzAni, P. (2004): First report of Obeliscoides cuniculi in European brown hare (Lepus europaeus). Parassitologia. 46 (Suppl. 1): 51.

PALACIOS, F. (1996): Systematics of the indigenous hares of Italy traditionally identified as Lepus europeus Pallas, 1778 (Mammalia: Leporidae). Bonner Zoologische Beiträge. 46: 59 - 91

Palacios, F., Orueta, J. F., TAPiA, G. G. (1989): Taxonomic review of the Lepus europaeus group in Italy and Corsica. Abstract of Papers and Poster, V International Theriological Congress. 1: 189-190

Pierpaoli, M., Riga, F., Trocchi, V., Randi, E. (1999): Species distinction and evolutionary relationships of the Italian hare (Lepus corsicanus) as described by mitochondrial DNA sequencing. Mol. Ecol. 8: 1805 - 1817. DOI: 10.1046/j.1365-294x.1999.00766.x

Poglayen, G., Gaglio, G., Brianti, E., Agretti, D., CAPelli, G. (2002): Monitoraggio sanitario della lepre (Lepus europaeus): la fauna parassitaria. Atti SISVet. 56: $199-200$

ReICZIGEL J., RózSA L. (2005): Quantitative Parasitology 3.0. Budapest.

Riga, F., Trocchi, V., Toso, S. (2001): Morphometric differentiation between the Italian hare (Lepus corsicanus De Winton, 1898) and European brown hare (Lepus europaeus Pallas, 1778). J. Zool. 253: 241 - 252. DOI: 10.1017/S0952836901000218

SAUlai, M., CABARET, J. (1998): Limited role of lagomorphs (Oryctolagus cuniculus and Lepus capensis) in the dispersion of parasite nematodes of ruminants. Vet. Parasitol. 77: 301 - 304. DOI: 10.1016/S0304-4017(98)00113-7 Sorgi, C., Tribulato, D., Miccichè, A., Billeri, F., Gaglio, G., Poglayen, G., Giannetto, S. (2004): A parasitological survey on wild rabbits (Oryctolagus cuniculus) living in Stagnone Archipelago natural preserve of Trapani, Italy. Parassitologia. 46 (Suppl. 1): 66.

Soulsby, E. J. L. (1968): Helminths, arthropods and Protozoa of Domesticated Animals. 7th Edition, London, Baillière Tindall, $809 \mathrm{pp}$

StanCAmpiano, L., BATtelli, G. (2002): Gastrointestinal 
nematodes of Chamois (Rupicapra rupicapra): relationship between host density and parasite community. Parassitologia. 44 (Suppl. 1): 176.

Stott, P., O’Callaghan, M., Phillips, P., Verbyla, A. (2009): The experimental establishment of ruminant nematodes in European hares (Lepus europaeus). Vet. Parasitol., 159: 82 - 85. doi: 10.1016/j.vetpar.2008.10.016 STRINGFELlOW, F. (1972): Comparative morphology of genital cones of Ostertagia from sheep in the United States. J. Parasitol. 58: 265 - 270.

STUNKARD, H.W. (1941): Studies on the Life History of the Anoplocephaline Cestodes of Hares and Rabbits. $J$. Parasitol., 27: 299 - 325.

Tenora, F., Murai, É., VAucher, C. (1986): On Andrya Railliet, 1893 and Paranoplocephala Lühe, 1910 (Cestoda, Monieziinae). Parasitol. Hung., 19: 43 - 75

RECEIVED JULY 29, 2011
Tizzani, P., Lavazza, A., Capucci L., Meneguz, P.G. (2002): Presence of infectious agents and parasites in wild population of cottontail (Sylvilagus floridanus) and consideration on its role in the diffusion of pathogens infecting hares. Proceeding of the IV Scientific Meeting of the European Association of Zoo- and Wildlife Veterinarians (EAZWV) joint with the Annual Meeting of the European Wildlife Disease Association (EWDA).

TrocchI, V., RIGA, F. (Eds) (2001): Piano d'azione nazionale per la Lepre italica (Lepus corsicanus). Quaderni di Conservazione della Natura 9: 1 - 108. Ministero dell'Ambiente, Istituto Nazionale per la Fauna Selvatica. Zaffaroni, E., Manfredi, M. T., CitTerio, C., SAla, M., Piccolo, G., LANFrANCHI, P. (2000): Host specificity of abomasal nematodes in free ranging alpine ruminants. Vet. Parasitol., 90: 221 - 230. DOI: 10.1016/S03044017(00)00240-5

ACCEPTED NOVEMBER 30, 2011 